\title{
Allelopathic Effects of Aqueous Leaf Extracts of Datura metel L. on Parthenium hysterophorus $L$.
}

\author{
Ramachandran $\mathrm{A}^{*}$ \\ Department of Agronomy, College of Agricultural Technology, India
}

Submission: July 27, 2017; Published: August 23, 2017

"Corresponding author: A Ramachandran, Assistant Professor, Department of Agronomy, College of Agricultural Technology, Theni, Tamil Nadu, India-625 562, Email: ramagri25@gmail.com

\section{Abstract}

Herbicidal activity of Datura metel L. was investigated against the noxious weed Parthenium hysterophorus L. In a laboratory bioassay, the effect of aqueous leaf extracts of $0,25,50$ and $75 \% \mathrm{w} / \mathrm{v}$ were tested. It caused maximum inhibition of germination and early seedling growth and fresh weight of Parthenium. In foliar spray bioassay of Datura metel L. aqueous leaf extract of 25, 50 and $75 \%$ w/v at two subsequent sprays were given at five day intervals on one-week and two-week old pots grown Parthenium seedlings. It caused $25 \%$ concentration of leaf extract was stimulated and higher concentration of 50 and 75\% leaf extracts was completely inhibited the seedling growth and shoot and root biomass and biochemical parameters, viz. Protein and chlorophyll were also measured to evaluate of Parthenium . The present study concludes that leaves of Datura metel L. contain herbicidal constituents for the management of Parthenium.

Keywords: Datura metel; Aqueous leaf extracts; Foliar spray; Seed germination; Seedling growth; Parthenium hysterophorus.

\section{Introduction}

Parthenium (Parthenium hysterophorus L.) is an aggressive weed of the family Asteracea. It is native to the subtropics of North and South America but now has invaded Asia, Africa and Australia during the last 50 years. Parthenium hysterophorus L. is an exotic weed which has become naturalized and which is spreading at an alarming rate all over India. This plant, popularly known as congress grass, is a defamed plant in view of its properties, since it causes health problems to man and domestic animals. At present, it is one of the most troublesome weeds in India, spreading rapidly in forests, pastures and agricultural lands. Several attempts have been made for its prevention, eradication and control, but to date without success [1].

The weed is characterized with high reproductive potential and fast growth rate, thus becomes dominant in a newly colonized area in a very short time [2]. The chemical analysis of Parthenium indicated that all the plant parts including trichomes and pollens contain toxins called sesquiterpene lactones. The major components of toxin being 'parthenin' and other phenolic acids such as caffeic acid, vanillic acid, anisic acid, chlorogenic acid and parahydroxy benzoic acid are lethal to human beings and animals [3].
The weed is known to cause allergic reactions in people. Symptoms are itching on exposed skin and development of a dermatitis which may spread over the whole body. It also causes asthma [2,4]. In addition of health hazards a lot of available data also highlights its impact on agriculture as well as natural ecosystems [5-7]. Parthenium is reported to be controlled by foliar spray of some chemical herbicides such as bromocil, diuron, terbacil, diquat, chlorimuron ethyl, metasulfuron methyl and buctril super [8-10]. However, control does not last long enough as expected due to the large amount of seeds deposited in the seed bank and flash germination of the seeds. Furthermore, increasing public concern on environmental issues requires alternative weed management systems which are less pesticide dependant or based on naturally occurring compounds [11].

Allelopathy as an ecological approach and allelochemicals as biological herbicides have been a challenge to current synthetic chemical approaches [12]. Numerous allelochemicals are involved in the allelopathic activities of the allelopathic plants; such as phenolics, terpenoids, alkaloids, coumarins, tannins, flavonoids, steroids and quinines [13]. Aqueous extracts of allelopathic grasses, allelopathic crops such as rice significantly suppressed 
the germination and growth of Parthenium weed [5,9]. Similarly, Shafiqueet al. [14] showed that aqueous extracts of allelopathic trees viz., Azadirachta indica (L.) A. Juss., Ficus bengalensis L., Melia azadarach L., Mangifera indica L., and Syzygium cumini (L.) Skeels significantly reduced the germination and early seedling growth of parthenium.

Datura metel L. is popular all over the world due to its medicinal uses. It is known for its antibacterial activity against burn pathogens $[15,16]$. The allopathic potenatial of Datura metel L. in largely unknown. The aim of the present study was to investigate allelopathic potential Datura metel L. on Parthenium.

\section{Materials and Methods}

The experiment where conducted in the Department of agronomy, Agricultural college and Research institute, Madurai, TamilNadu. The leaves of Datura metel L. were collected from May to June 2014.

\section{Preparation of extracts}

Fresh leaf materials of $D$. metel L. were collected and were thoroughly washed with tap water, followed by washing with sterilised water and blended at $100 \mathrm{~g} .100 \mathrm{ml}-1$ of distilled water and left for 2 hours at $20^{\circ} \mathrm{C}$. These were filtered through a muslin cloth followed by Whatmann No. 1 filter paper. $100 \%$ this stock solution was further diluted to get 25,50 and $75 \% \mathrm{w} / \mathrm{v}$ solutions. The extracts were used in the experiments on the same day.

\section{Laboratory bioassay}

In a laboratory bioassay, the effect of different concentrations of leaf extracts on germination and early seedling growth of Parthenium was studied. For this, 10 seeds of Parthenium were placed in a $9 \mathrm{~cm}$ diameter Petri plate lined with a filter paper, and moistened with $3 \mathrm{ml}$ of different concentrations of leaf extracts and a control with distilled water was do maintain. Each treatment was replicated thrice. Petri plates were arranged in a completely randomized design in a growth chamber maintained at $25{ }^{\circ} \mathrm{C}$ and $12 \mathrm{~h}$ light period daily. After seven days, Seed germination, seedling root/shoot length and fresh biomass determined.

\section{Foliar spray bioassay}

Parthenium seeds were sown in mud pots of $15 \mathrm{~cm}$ diameter and $15 \mathrm{~cm}$ deep, filled with $600 \mathrm{~g}$ sandy loam soil. Initially, ten seeds were sown in each pot, which were thinned to three uniform seedlings one week after germination. The freshly prepared extracts of 25,50 and $75 \% \mathrm{w} / \mathrm{v}$ were sprayed on the surface of one-week and two-week-old Parthenium plants with a hand sprayer. Two subsequent sprays were similarly given as 5 and 10 days after of the first spray. Control plots were similarly sprayed withwater. Each treatment was replicated thrice. The Seedlings were harvested after 4 weeks after sowing the seedlings washed under tap water to remove soil sticking on the roots. The seedlings were sampled for biophysical and biochemical parameters. Length of root and height of shoot were recorded and the fresh (FW) and dry weight DW) of seedling were measured. The dry weight was measured after drying the samples for $80{ }^{\circ} \mathrm{C}$ in oven for dry weight. Data regarding the length and Plant biomass of both roots and shoots were recorded.

\section{Chlorophyll content}

The amount of chlorophyll was determined following the method of Arnon [17]. 10mg of first fully expanded fresh leaves of each plant under treatments were ground with neutral sand and $10 \mathrm{ml}$ of $80 \%$ acetone and centrifuged at $3000 \mathrm{rpm}$ for 10 minutes. Supernatant was used to measure optical density. Optical density was measured at $645 \mathrm{~nm}$ and $663 \mathrm{~nm}$. Chlorophyll $\mathrm{a}, \mathrm{b}$ and total chlorophyll were calculated as follow:

$$
\begin{aligned}
& \text { Total chlorophyll }(\mathrm{mg} / \mathrm{g})=\frac{20.2 \times O D_{645}+8.02 \times O D_{663}}{1000 \times \mathrm{W}} \mathrm{XV} \\
& \text { Total chlorophyll } \mathrm{a}(\mathrm{mg} / \mathrm{g})=\frac{12.7 \times O D_{663}-2.69 \times O D_{645}}{1000 \times \mathrm{W}} \mathrm{XV} \\
& \text { Total chlorophyll } b(\mathrm{mg} / \mathrm{g})=\frac{22.9 \times O D_{645}}{1000 \times \mathrm{W}} 4.68 \times D_{645} \\
& X V
\end{aligned}
$$

Where $\mathrm{V}=$ volume of the supernatant in $\mathrm{ml}, \mathrm{W}=$ fresh weight of the leaves in gm and $\mathrm{OD}=$ Optical density.

\section{Quantitative estimation of protein}

Quantitative estimation of protein was done following the method of Lowry et al. [18]. Ten mg of first fully expanded fresh leaves of each plant under treatments was homogenized with $1 \mathrm{ml}$ of $\mathrm{NaOH}$ for 5 minutes at $100^{\circ} \mathrm{C}$. Then $5 \mathrm{ml}$ of alkaline copper reagent was added. After 10 minutes at room temperature $0.5 \mathrm{ml}$ of Folin -Ciocalteau reagent was added and mixed in a tube. The absorbance $650 \mathrm{~nm}$ was measured after 30 minutes. The amount of protein was calculated with reference to standard curve of bovine serum albumin.

\section{Statistical analysis}

The experimental data collected from three replications were subjected to statistical scrutiny as be the method suggested by Gomez and Gomez (1984) as $\mathrm{P} \leq 0.05$ to compare the treatment means.

\section{Results and Discussion}

\section{Effect of leaf extract on germination and early seedling growth}

Aqueous leaf extract of $D$. metel delayed seed germination as well as reduced the final germination percentage of parthenium. The extract was highly toxic and even the lowest concentration of the extract (25\%) significantly reduced the final germination by $86.66 \%$ as compared with control. The increase in extract concentration resulted in a corresponding decrease in germination. The 50 and $75 \%$ extracts reduced the germination by $100 \%$ as compared with control.

In laboratory bioassays, highly reduced the root and shoot growth of Parthenium was D. metel leaf extracts. Effects of 
different aqueous leaf extracts concentrations of on root and shoot length were variable. Lower concentrations of $25 \%$ significantly reduced root and shoot length by 73.27 and $74.61 \%$ respectively. In contrast, higher concentrations of 50 and $75 \%$ reduced root and shoot length by 100 and $100 \%$, respectively. Lower concentrations of $25 \%$ significantly reduced the plant biomass $75.65 \%$ respectively. However, the higher concentrations of 50 and $75 \%$ significantly reduced the plant biomass by $100 \%$, respectively (Table $1 \& 2$ ).

Table 1: Effect of different concentrations of aqueous leaf extract of Datura metel L. on the seed germination of Parthenium hysterophorus L. in laboratory bioassays.

\begin{tabular}{|c|c|}
\hline Treatments & Seed Germination (\%) \\
\hline $\mathrm{C}$ & 100 \\
\hline $\mathrm{T} 1$ & -89.17 \\
\hline & 13.33 \\
\hline $\mathrm{T} 2$ & -18.43 \\
\hline & 0 \\
\hline $\mathrm{T} 3$ & -0.82 \\
\hline & 0 \\
\hline $\mathrm{SEd}$ & -0.82 \\
\hline $\mathrm{CD}(\mathrm{P}=0.05)$ & 1.91 \\
\hline
\end{tabular}

Table 2: Effect of different concentrations of aqueous leaf extract of Datura metel L. on the early seedling growth of Parthenium hysterophorus L. in laboratory bioassays.

\begin{tabular}{|c|c|c|c|}
\hline Treatments & $\begin{array}{c}\text { Root length } \\
\text { (mm) }\end{array}$ & $\begin{array}{c}\text { Shoot length } \\
\text { (mm) }\end{array}$ & $\begin{array}{c}\text { Plant fresh wt. } \\
\text { (mg) }\end{array}$ \\
\hline C & 20.54 & 12.84 & 6.98 \\
\hline & -3.18 & -2.81 & -2.39 \\
\hline T1 & 5.49 & 3.26 & 1.42 \\
\hline & -2.23 & -1.97 & -1.68 \\
\hline T2 & 0 & 0 & 0 \\
\hline & -1.38 & -1.38 & -1.38 \\
\hline T3 & 0 & 0 & 0 \\
\hline & -1.38 & -1.38 & -1.38 \\
\hline SEd & 0.11 & 0.06 & 0.02 \\
\hline CD (P=0.05) & 0.23 & 0.15 & 0.06 \\
\hline
\end{tabular}

Figures in the parentheses are log $(X+4)$ transformed values, $\mathrm{C}=$ Control, $\mathrm{T} 1=25 \%, \mathrm{~T} 2=50 \%, \mathrm{~T} 3=75 \%$ aqueous leaf extracts concentrations

Similar effects of plant extracts have been reported against Parthenium [7]. These results support the earlier findings that the seedling growth of Parthenium can be checked by aqueous extracts of allelopathic plant species. Similar inhibition in germination of Parthenium seeds has also been reported due to aqueous leaf extracts of other allelopathic tree species viz., Azadirachta indica (L.) A. Juss., Ficus bengalensis L., Melia azadarach L., Mangifera indica L., and Syzygium cumini (L.) Skeels [14]. Our results are also in agreement with the findings of Anjum et al. [19] Javaid \& Anjum [9] who reported that aqueous extracts of allelopathic grasses viz., Imperata cylindrica (L). Beauv., Desmostachya bipinnata Stapf., Dicanthium annulatum Stapf., Cenchrus pennisetiformis Hochest and Sorghum halepense Pers., significantly suppressed the germination of Parthenium.

\section{Foliar spray bioassay}

Chlorophyll and protein contents of Parthenium plants decreased when treated with aqueous leaf extract of $D$. metel L. Maximum reduction of Chlorophyll and protein contents were recorded in seedlings of Parthenium treated with aqueous leaf extract of $D$. metel L. the seedlings treated with highest concentration of aqueous leaf extract of $D$. metel L. did not survive. Minimum amount of total chlorophyll and protein content was recorded in Parthenium treated with aqueous leaf extracts of $25 \%$ concentration while lower concentration increased the chlorophyll and protein contents but highest ( 50 and $75 \%$ ) concentrations of aqueous leaf extracts completely inhibited the chlorophyll and protein contents.

The aqueous leaf extract $25 \%$ concentration of Datura metel L. stimulated the root growth and shoot growth and highest aqueous leaf extracts (50 and 75\%) concentration of Datura metel L. inhibited the root growth and shoot growth. The number of leaves per plant decreased to the minimum with aqueous leaf extracts of $25 \%$ concentration. Highest concentration of aqueous leaf extracts (50 and 75\%) maximum reduction in number of leaves per plant.

The treatment with aqueous leaf extracts $25 \%$ concentration decreasing trend of fresh weight and dry weight of root and shoot but successively completely inhibited in the treatments with other concentration of (50 and 75\%) aqueous leaf extracts of Datura metel L.

In a recent study, Javaid et al. [9] have reported that foliar spray with aqueous extracts of sunflower (Helianthus annuus L.) and sorghum (Sorghum bicolor L.) significantly suppressed the growth of parthenium. This reveals that only the polar compounds in the leaves of D. metel L. are toxic against the germination and growth of Parthenium. Various with anolide compounds have been isolated from D. metel L. which may be responsible for the herbicidal activity of this medicinal plant against the Parthenium weed. In addition, sphingosine derivatives such as $(4 \mathrm{E}, 8 \mathrm{Z})$ - 1 - O-(Bd - glucopyranosyl)-N-(2hydroxyhex-adecanoyl )-sphinga-4,8 die nine [20] and a pyrrole derivative, namely $2 \beta$ (3,4-dimethyl-2,5-dihydro-1H-pyrrol-2yl)-10-methylethyl pentanoate, have also been isolated from leaves of $D$. metel L. which may be responsible for the herbicidal activity of the plant [21-25].

\section{Conclusion}

The present study clearly indicates that aqueous leaf extracts of $D$. metel contain germination and growth inhibitors against Parthenium weed. Further studies are required to isolate and identify their herbicidal constituents, especially from leaf of D. 
metel. These natural compounds may be used as a structural lead for the synthesis of natural product-based herbicides for the control of one of the world's worst environmentally-polluting weeds.

\section{References}

1. Kavita G, Nagendra B (2000) Effect of Vermicompost of Parthenium on two cultivars of wheat. Ind J Ecol 27: 177-180.

2. Kohli RK, Rani D (1994) Partheniumhysterophorus L. a review. Res Bull (Sci) Punjab Univ India 44: 105-119.

3. Oudhia P (1998) Parthenium: A curse for the biodiversity of Chhattisgarh plain. In: Abstract National Research Seminar on Biochemical changes. An impact on Environment RD Govt PG College, Mandla, Madhya Pradesh, India, p. 26.

4. Evans HC (1997) Partheniumhysterophorus: a review of its weed status and the possibilities for biological control. Biocontrol News and Information 18(3): 89-98.

5. Anjum T, Bajwa R, Javaid A (2005) Biological Control of Parthenium I: Effect of Imperatacylindrica on distribution, germination and seedling growth of PartheniumhysterophorusL. Int J Agric Biol 7: 448-450.

6. Javaid A, Shafique S, Shafique S (2009) Invasion of noxious alien weed Partheniumhysterophorus L. in grazing lands of Lahore, Pakistan. J Anim Plant Sci 19: 149-153.

7. Belz RG, Reinhardt CF, Foxcroft LC, Hurle K (2007) Residue allelopathy in PartheniumhysterophorusL. -Does parthenin play a leading role? Crop Prot 26: 237-245.

8. Mishra JS, VM Bhan (1994) Efficacy of sulphonyl urea herbicides against Parthenium hysterophorus L. Weed News 1: 16.

9. Javaid A, Anjum T (2006) Control of Parthenium hysterophorus L. by aqueous extracts of allelopathic grasses. Pak J Bot 38(1): 139-146.

10. Javaid A, Riaz T (2007) Effect of aqueous extracts of allelopathic crops on germination and growth of Partheniumhysterophorus L. in district Okara, Pakistan J Anim Plant Sci 17: 59-62.

11. Singh HP, DR Batish, RK Kohli (2003) Allelopathic interactions and allelochemicals: New possibilities for sustainable weed management. Crit Rev Plant Sci 22: 239-311.

12. El-Rokiek KG, TA El-Sahahawy, FA Sharara (2006) New approach to use rice straw waste for weed control. II: The effect of rice straw extract and fusillade on some weeds infesting soybean. Int J Agric Biol 8: 269275 .
13. Xuan TD, S Tawata, TD Khanh, IM Chung (2005) Biological control of weeds and plants pathogens in paddy rice by exploiting plant allelopathy: an overview. Crop Prot 24: 197 -206.

14. Shfique S, Bajwa R, Javaid A, Shfique S (2005) Biological control of Parthenium. IV. Suppressive ability of aqueous leaf extracts some allelopathic trees against germination and early seedling growth of Parthenium hysterophorus. Pak J Weed Sci Res 11: 75-79.

15. Gnanamani A, Priya KS, Radhakrishnan N, Babu M (2003) Antibacterial activity of two plant extracts on eight burn pathogens. J Ethnopharmacol 86(1): 59-61.

16. Priya SK, Gnanamani A, Radhakrishnan N, Babu M (2002) Healing potential of Daturametel on burn wounds in albino rats. J Ethnopharmacol 83: 193-199.

17. Arnon DI (1949) Copper enzymes in isolated chloroplasts polyphenoloxidase in Beta vulgaris Plant Physiol 24(1): 1-15.

18. Lowry OH, NJ Rosebrough, AL Farr RJ Randal (1951) Protein measurement with the Folin-phenol reagent. J Biol Chem 193(1): 265275.

19. Javaid A, T Anjum, R Bajwa (2005) Biological control of Parthenium II: Allelopathic effect of Desmostachyabipinnata on distribution and early seedling growth of Parthenium hysterophorus L. Int J Biol Biotech 2: 459-463.

20. Dabur R, Ali M, Singh H, Gupta J, Sharma GL (2004) A novel antifungal pyrrole derivative from Datura metel leaves. Pharmazie 59(7): 568570 .

21. Sahai M, Manickam M, Gupta M, Srivastava A, Ray AB (1999) Characterisation of a cerebroside isolated from the leaves of Datura metel. Journal of the Indian Chemical Society 76(2): 95-99.

22. Javaid A, Shafique S, Bajwa R, Shafique S (2006) Effect of aqueous extracts of allelopathic crops on germination and growth of Parthenium hysterophorus L. South African J Bot 72: 608-611.

23. Kagale S, Marimuthu T, Thayumanavan B, Nandakumar R, Samiyappan R (2004) Antimicrobial activity and induction of systemic resistance in rice by leaf extract of Datura metel against Rhizoctonia solani and Xanthomonas oryzaepv. oryzae. Physiology and Molecular Plant Pathology 65: 91-100.

24. Sahai M, Manickam M, Gupta M, Srivastava A, Ray AB (1999) Characterisation of a cerebroside isolated from the leaves of Daturametel. Journal of the Indian Chemical Society 76(2): 95-99.

25. Suresh PV, Gupta D Behera, Jindal SK (1994) Bronchial provocation with Parthenium pollen extract in bronchial asthma. Indian J Chest Dis Allied Sci 36: 104

\section{Your next submission with Juniper Publishers will reach you the below assets}

- Quality Editorial service

- Swift Peer Review

- Reprints availability

- E-prints Service

- Manuscript Podcast for convenient understanding

- Global attainment for your research

- Manuscript accessibility in different formats

( Pdf, E-pub, Full Text, Audio)

- Unceasing customer service

Track the below URL for one-step submission https://juniperpublishers.com/online-submission.php 